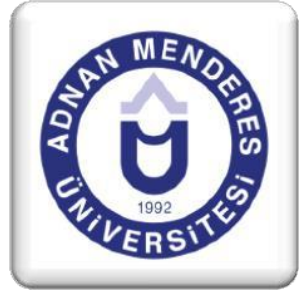

\title{
Öğretmen Adaylarının Çoklu Zekâ Bölümlerine İlişkin Algılarının Karşılaştırmalı Perspektiften İncelenmesi
}

\author{
Adil Adnan ÖZTÜRK ${ }^{1}$, Nesrin ÖZSOY ${ }^{2}$, Ruken Akar \\ VURAL $^{3}$, Sultan BAYSAN ${ }^{4}$
}

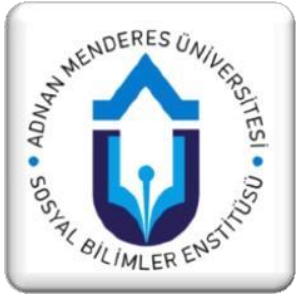

\section{ÖZET}

Çoklu Zekâ Teorisi, eğitim bilimleri açısından, öğretim stratejileri, öğretim programlarına entegrasyon ve öğrenenlerin değerlendirilmeleri yönlerinden önemlidir. Bu çalışma öğretmen adaylarının çoklu zekâ bölümlerine ilişkin algısını karşılaştırmalı olarak analiz etmeyi amaçlamaktadır. Araştırma tarama modelinde olup, var olan durumu betimlemeyi amaçlayan bir yaklaşıma sahiptir. Araştırmanın örneklemini, Adnan Menderes Üniversitesi Eğitim Fakültesinde 2016-2017 Akademik Yılında öğrenim gören 358 öğretmen adayı oluşturmaktadır. Araştırmada veri toplama aracı olarak Saban (2002) tarafindan geliştirilen "Çoklu Zekâ Alanları Envanteri" uygulanmıştır. Öğretmen adaylarının özellikle doğacı, içsel ve kişiler arası zekâ bölümlerinde genel puan ortalamaları diğer zekâ bölümlerine göre daha yüksek çıkmıştır. Müzik Eğitimi öğretmen adaylarının müzikselritmik zekâ bölümü ortalama puanları en yüksek ortalamaya sahiptir. Ancak, bölümleri itibariyle yüksek puan ortalamaları beklenen Resim öğretmeni adaylarının görsel-uzamsal zekâ bölümüne ilişkin ortalama puanları ile Beden Eğitimi öğretmen adaylarının bedensel-kinestetik zekâ bölümü ortalamaları görece düşüktür.

Anahtar Kelimeler: Çoklu Zekâ Kuramı, Çoklu Zekâ Envanteri, öğretmen adayları, algı.

\section{A Multi-Perspective Comparison of Prospective Teacher's Self Perceptions of their Multiple Intelligence Areas}

\begin{abstract}
Multiple Intelligence (MI) theory has three basic aspects (teaching strategies, curricular adaptations, and student assessment) for educational sciences. This study aims to investigate comparatively the perception of multiple intelligence areas of teacher candidates. The research designed as a descriptive model and has an approach aimed at describing the existing situation. The sample of the research is composed of the 358 prospective teachers who are educated in the Adnan Menderes University, Faculty of Education in the 2016-2017 Academic Year. "Multiple Intelligence Areas Inventory" developed by Saban (2002) was applied as a data collection tool in the survey. The results indicate that the teacher candidates, especially in the naturalist, inner and interpersonal intelligence areas, are higher than the other intelligence areas of the mean average. Music Education teacher candidates have the highest average scores in the musical-rhythmic intelligence area. However, the average scores of the visual-spatial intelligence area of the visual arts teacher candidates who are expected to have a high score average are low. Moreover, the average of the physical-kinesthetic intelligence areas of the Physical education teacher candidates are also lower than expected.
\end{abstract}

Keywords: Multiple Intelligence Theory, Multiple Intelligence Inventory, teacher candidates, perception.

\footnotetext{
${ }^{1}$ Yrd.Doç.Dr., Adnan Menderes Üniversitesi, Eğitim Fakültesi, Türkçe ve Sosyal Bilimler Eğitimi, Efeler Aydın, adil_adnanozturk@hotmail.com

2 Prof.Dr. Adnan Menderes Üniversitesi, Eğitim Fakültesi, Matematik Eğitimi, Efeler Aydın, nesrinozsoy@yahoo.com

3 Doç.Dr. Adnan Menderes Üniversitesi, Eğitim Fakültesi, Eğitim Bilimleri Bölümü, Efeler Aydın, rakarvural@gmail.com

${ }^{4}$ Prof.Dr. Adnan Menderes Üniversitesi, Eğitim Fakültesi, Türkçe ve Sosyal Bilimler Eğitimi, Efeler Aydın, sbaysan@adu.edu.tr
} 


\section{Giriș}

Çoklu Zekâ Kuramı, 1983 yılında ABD’de Harward Üniversitesi öğretim üyesi Howard Gardner tarafindan 1983 y1lında ortaya atılmıştır. Gardner zekâyı, "bir veya daha fazla kültürel yapıda değeri olan bir ürüne şekil verme ya da problemleri çözme yeteneği”" olarak tanımlamıştır. Gardner, her bireyin farklı derecede çeşitli zekâlara sahip olduğunu ileri sürmüş, zekânın birden çok alanda ölçülebileceğini, doğuştan kalıtımla geldiğini ve geliştirilebileceğini ifade etmiştir. Teori kısa sürede eğitim alanında geniş uygulama alanları bulmuştur. (Armstrong, 1994, Gardner, 1993, Karabay vd. 2011).

Çoklu zekâ kuramının dayandığı temel ilkeler aşağıda sıralanmıştır:

1. Bütün bireyler, sekiz zekâ alanının tamamına sahiptir.

2. Birçok birey, bu zekâ alanlarını belli bir düzeye kadar geliştirebilir.

3. Zekâ alanları, büyük sıklıkla karmaşık bir şekilde bir arada çalışırlar.

4. Zekâ alanlarına göre bireyin bir alanda zeki olduğunun belirleyicileri çok çeşitlidir. Zekâ alanlarında yeterliliğe ilişkin kesin ölçütler bulmak güçtür (Armstrong, 1994; Campbell, 1996).

Yaklaşımın en önemli ilkesi, zekânın çoklu olması ve sürekli gelişim göstermesidir. Gardner'a göre her insanda sözel-dilbilimsel, mantıksal-matematiksel, müzikal-ritmik, bedensel-duyusal, uzaysal-görsel zekâ, kişiler arası-sosyal ve kişisel-öze dönük ve doğacı zekâ olmak üzere sekiz farklı zekâ türü bulunur. Bu yaklaşıma göre, her insanın bireysel bir öğrenme yolu bulunmaktadır. Yaklaşımın esası, bireyin öğrenmede zorlandığı birçok şeyin öğretilebilir olduğuna ve eğitim sürecinde önemli olanın, her çocuğun öğreneceği stili keşfedip uygun yöntem ya da yöntemlerin seçilmesi gerektiğine dayanmaktadır. Bir program geliştirilirken ya da bir öğretim etkinliği planlanırken öğrencilerdeki bireysel öğrenme farkl11ıkları, ilgileri, öğrenme stilleri, gereksinimleri, öğrenmede güçlük çektikleri konu, kavram ve işlemlerde çoklu zekâ yaklaşımı sınıf içi etkinlik ve uygulamalarda yardımcı olabilmektedir (Azar, Presley ve Balkaya 2006).

Çoklu zekâ yaklaşımında amaç sadece öğrencilerin akademik başarılarını artırmak değil, aynı zamanda çoklu zekâ potansiyellerini tespit edip geliştirmektir. Bir öğrenme psikologu olan Gardner zekâ kavramına farklı bir boyut getirmiş ve insanlardaki zekânın tek bir boyutta değil, çok farklı boyutlarda değerlendirilmesi gerçeğini ileri sürmüştür (Kabapınar, 2007). Gardner, yıllar boyu hâkimiyetini sürdüren, insanların tek bir zekâya sahip oldukları IQ (Intelligence Quotient) denilen zekâ anlayışını kıran kişi olarak eğitim tarihine geçmiştir. Ona göre insanların sahip oldukları çoklu zekâların her biri yaşamak, öğrenmek ve insan olmak için kullanılan etkili birer araçtır. Bir öğrenme-öğretme yaklaşımı olarak tanımlanabilecek ve bireylerin farklı yollarla öğrenebilmesinin yollarını açacak zenginleştirilmiş öğrenme-öğretme çevrelerinin düzenlenmesinde "Çoklu Zekâ Yaklaşımı" önemli bir araçtır. Bu nedenle de öğretmen adaylarının hem kendi öğrenme yolları hem de öğrencilerinin öğrenmedeki bireysel farklılıklarını keşfetmeli ve farklı öğrenenlere yönelik öğrenme-öğretme çevresi düzenleme becerilerine sahip olmalıdır. Lazear'ın da (1992) vurguladığı gibi, öğretmen öğrencilerin güçlü ve zayıf zekâ alanlarını ana hatları ile belirleyebilirse, onların öğrenirken hangi yolları kullanabileceğini de öğretebilir. Noble'ın (2004) öğretmenler üzerinde yürüttügü çalışma da öğretmenlerin çoklu zekâ yaklaşımının farkında olmasının olumlu etkilerini göstermektedir. Sözü edilen çalışmaya katılan öğretenlerin yarıdan fazlası, çoklu zekâ etkinliklerinin Bloom'un revize taksonomisi ile 
harmanlandığında, çocukların öz farkındalıklarını artırdığını ve diğer arkadaşlarının farklı öğrenme biçimlerine de saygı duymaya başladıklarını vurgulamışlardır.

$\mathrm{Bu}$ gerekçelerle yola çıkılan çalışmanın temel amacı, eğitim fakültesi öğrencileri ve pedagojik formasyon programına devam eden öğretmen adaylarının sahip oldukları çoklu zekâ alanlarına ilişkin farkındalıklarını belirlemektir. $\mathrm{Bu}$ temel amaç doğrultusunda aşağıdaki sorulara yanıt aranmıştır.

1. Öğretmen adaylarının devam ettikleri bölüm ile Çoklu Zekâ Envanteri "Sözel/ Dilsel Zekâ Alanı"na ilişkin alt boyut toplam puanları arasında farklılaşma var mıdır?

2. Öğretmen adaylarının devam ettikleri bölüm ile Çoklu Zekâ Envanteri "Mantıksal/ Matematiksel Zekâ Alanı"na ilişkin alt boyut toplam puanları arasında farklılaşma var midir?

3. Öğretmen adaylarının devam ettikleri bölüm ile Çoklu Zekâ Envanteri "Görsel/Uzamsal Zekâ Alanı"na ilişkin alt boyut toplam puanları arasında farklılaşma var midir?

4. Öğretmen adaylarının devam ettikleri bölüm ile Çoklu Zekâ Envanteri “Müziksel/Ritmik Zekâ Alanı"na ilişkin alt boyut toplam puanları arasında farklılaşma var midir?

5. Öğretmen adaylarının devam ettikleri bölüm ile Çoklu Zekâ Envanteri "Bedensel/Kinestetik Zekâ Alanı"na ilişkin alt boyut toplam puanları arasında farklılaşma var mıdır?

6. Öğretmen adaylarının devam ettikleri bölüm ile Çoklu Zekâ Envanteri "Doğacı Zekâa Alanı"na ilişkin alt boyut toplam puanları arasında farklılaşma var mıdır?

7. Öğretmen adaylarının devam ettikleri bölüm ile Çoklu Zekâ Envanteri "Kişilerarası Zekâ Alanı"na ilişkin alt boyut toplam puanları arasında farklılaşma var mıdır?

8. Öğretmen adaylarının devam ettikleri bölüm ile Çoklu Zekâ Envanteri "İçsel Zekâa Alanı"na ilişkin alt boyut toplam puanları arasında farklılaşma var mıdır?

\section{Yöntem}

Araştırma tarama modelinde olup, var olan durumu betimlemeyi amaçlayan bir yaklaşıma dayanmaktadır (Karasar, 2009). Araştırmanın örneklemini, Adnan Menderes Üniversitesi Eğitim Fakültesinde 2016-2017 Akademik Yılında öğrenim gören 358 öğretmen aday1 oluşturmaktadır. Araştırmada veri toplama aracı olarak Saban (2002) tarafindan geliştirilen "Çoklu Zekâ Alanları Envanteri", ölçekten daha güvenilir sonuç almak için maddeler karıştırılarak öğretmen adaylarına uygulanmıştır.

\section{1.Çalışma Grubu}

Araştırmanın örneklemini, Eğitim Fakültesi öğrencileri ve Pedagojik Formasyon Programına devam eden, toplam 358 öğretmen adayı oluşturmaktadır. Tablo 1'de örneklemi oluşturan öğrencilerin devam ettikleri bölümlere göre dağılımı bulunmaktadır. 
Tablo 1. Örneklemi Oluşturan Öğretmen Adaylarının Bölümlere Göre Dă̆llımı

\begin{tabular}{|c|c|}
\hline Bölüm & Frekans \\
\hline Sosyal Bilgiler Öğretmenliği & 80 \\
\hline Psikolojik Danışma ve Rehberlik (PDR) & 60 \\
\hline Fen Bilgisi Öğretmenliği & 41 \\
\hline Bilgisayar ve Öğretim Teknolojileri (BÖTE) & 29 \\
\hline Sosyoloji (*) & 28 \\
\hline Hemşirelik (*) & 24 \\
\hline Resim Öğretmenliği & 19 \\
\hline İşletme $(*)$ & 18 \\
\hline Müzik Öğretmenliği & 15 \\
\hline Sınıf Öğretmenliği & 9 \\
\hline Arkeoloji (*) & 8 \\
\hline Beden Eğitimi ve Spor $(*)$ & 7 \\
\hline Tarih $(*)$ & 6 \\
\hline Matematik $(*)$ & 5 \\
\hline Kamu Yönetimi (*) & 4 \\
\hline Radyo, TV, Sinema (*) & 3 \\
\hline İlahiyat $(*)$ & 2 \\
\hline Toplam & 358 \\
\hline
\end{tabular}

(*) işareti olan bölümler Öğretmenlik Formasyon Programı kapsamındaki adayları göstermektedir.

\subsection{Veri Toplama Araçları}

$\mathrm{Bu}$ araştırmada Tablo 1'de belirtilen bölümlerde öğrenim görmekte olan öğretmen adaylarına Saban (2002) tarafından geliştirilen ve Likert türünde hazırlanmıştır. Toplam 10 bölüm ve 80 maddeden oluşan Çoklu Zekâ Alanları Envanteri daha güvenilir sonuç almak amacıyla maddeler karıştırılarak uygulanmıştır. Envanterin her bölümünde 8 zekâ alanından sorular bulunmaktadır. Maddeler beşli dereceleme sistemine göre hazırlanmıştır. " $0=$ Bana hiç uygun değil, 1=Bana çok az uygun, 2=Bana kısmen uygun, 3=Bana oldukça uygun ve 4=Bana tamamen uygun biçiminde sıralanmıştır. Çoklu Zekâ Alanları Envanteri öğretmen adaylarına 2016-2017 Akademik Yılı Bahar döneminde uygulanmıştır. Uygulama öncesinde, araştırmaya katılan öğretmen adaylarına öncelikle araştırmanın amacı hakkında bilgi verilmiş ve gerçek duygu ve düşüncelerini yansıtabilmeleri amaciyla öğretmen adaylarının cevap kâğıtlarına isim yazmamaları istenmiş; maddelerin yerleri öğretmen adaylarının kendilerinin çoklu zeka alanlarına ilişkin önyargılarını engellemek amacıyla değiştirilmiştir. Böylelikle, araştırmanın güvenilirliğinin arttırılması amaçlanmıştır. 


\subsection{Verilerin Analizi}

Öğretmen adaylarının Çoklu Zekâ Alanları Envanteri’ne vermiş oldukları cevapların analizi ve yorumlanması esnasında, öncelikle adayların her bir zekâ alanını ilgilendiren maddelere verdikleri yanıtlara ilişkin toplam puanlar hesaplanmıştır. Ardından da, her bir zekâ alanı için ayrı olarak belirlenen bu toplam puanlar üzerinden öğretmen adaylarının bu zekâ alanlarına ilişkin gelişmişlik düzeyleri belirlenmiştir. Buna göre, her bir zekâ alanı için toplam puan 32-40 arasında ise zekâ alanındaki gelişmişlik düzeyi çok gelişmiş, toplam puan 24-31 arasında olduğunda da zekâ alanındaki gelişmişlik düzeyi gelişmiş olarak kabul edilmiştir. Bununla birlikte, 16-23 arasındaki toplam puan orta düzeyde gelişmişs zekâ alanını, 8-15 arasındaki toplam puan $a z$ gelişmiş zekâ alanını ve 0-7 arasındaki toplam puan da zekâ alanının gelişmediğini göstermektedir.

Bilgisayar ortamında SPSS 6.0 programı ile çözümlenen verilerin normal dağılım durumları incelenmiş, varsayımların sağlandığı belirlenmiştir. Veriler, aritmetik ortalamalar ve tek yönlü varyans analizinden (ANOVA) yararlanılarak yorumlanmıştır. İstatistiksel analizler alt ölçeklere ilişkin toplam puanlar üzerinden yapılmıştır. Anlamlılık düzeyi .05 olarak alınmıştır. Ortalamalar arasında gözlenen farkın hangi gruplar arasında olduğunu belirlemek için Tukey HSD (Tukey Gerçekten Önemli Fark) Testi'nden yararlanılmıştır. Elde edilen veriler, ANOVA koşullarını karşılamaktadır. Farklı gözeneklerdeki örneklem büyüklüğü çalışmanın bir sınırlılığını ifade etmekte ancak, ANOVA koşullarına aykırı düşmemektedir (Keppel, 1993).

Araştırmanın amacına ilişkin bulgular Çoklu Zekâ Envanteri'nin alt ölçeklerine göre ayrı ayrı analiz edilerek Bulgular bölümünde sunulmuştur.

\section{Bulgular}

$\mathrm{Bu}$ bölümde öğretmen adaylarının çoklu zekâ testinin her bir alt boyutundan aldıkları puanlar, öğretmen adaylarının öğrenim gördükleri bölümlere göre değerlendirilmiştir.

3.1. Sözel/Dilsel Zekâ Alanı: Öğretmen adayları branşlarına göre sözel/dilsel zekâ alanı açısından incelenmiş; inceleme sonuçları Tablo 2'de sunulmuştur. Aritmetik ortalamalar ve varyans analizinden (One-way) yararlanılmıştır.

Tablo .2 Sözel/Dilsel Zekâ Alanına İlişkin Ortalama ve Standart Sapma Sonuçları

\begin{tabular}{lcccccc}
\hline Bölüm & Sayı & Ortalama & $\begin{array}{l}\text { Standart } \\
\text { Sapma }\end{array}$ & $\begin{array}{l}\text { Standart } \\
\text { Hata }\end{array}$ & $\begin{array}{l}\text { Minimum } \\
\text { Değer }\end{array}$ & $\begin{array}{l}\text { Maksimum } \\
\text { Değer }\end{array}$ \\
\hline Sosyal Bilgiler & 80 & 27.90 & 5.698 & .637 & 14.00 & 40.00 \\
PDR & 60 & 26.28 & 5.663 & .731 & 17.00 & 37.00 \\
Fen Bilgisi & 41 & 25.78 & 6.962 & 1.087 & 10.00 & 40.00 \\
BÖTE & 29 & 25.27 & 7.045 & 1.308 & 12.00 & 38.00 \\
Sosyoloji & 28 & 26.10 & 6.361 & 1.202 & 12.00 & 35.00 \\
Hemşirelik & 24 & 27.08 & 5.807 & 1.185 & 16.00 & 37.00 \\
Resim Öğretmenliği & 19 & 22.57 & 6.103 & 1.400 & 13.00 & 32.00 \\
İşletme & 18 & 26.94 & 6.291 & 1.482 & 14.00 & 38.00 \\
Müzik Öğretmenliği & 15 & 27.93 & 4.861 & 1.255 & 20.00 & 35.00 \\
\hline
\end{tabular}




\begin{tabular}{lcccccc}
\hline Sinıf Öğretmenliği & 9 & 30.77 & 4.763 & 1.587 & 23.00 & 35.00 \\
Arkeoloji & 8 & 28.50 & 3.585 & 1.267 & 24.00 & 34.00 \\
Beden Eğitimi & 7 & 26.71 & 5.879 & 2.222 & 15.00 & 34.00 \\
Tarih & 6 & 31.50 & 5.049 & 2.061 & 25.00 & 38.00 \\
Matematik & 5 & 24.20 & 5.167 & 2.310 & 18.00 & 30.00 \\
Kamu & 4 & 29.00 & 4.320 & 2.160 & 25.00 & 35.00 \\
Radyo, TV, Sinema & 3 & 25.33 & 5.507 & 3.179 & 19.00 & 29.00 \\
İlahiyat & 2 & 26.50 & 2.121 & 1.500 & 25.00 & 28.00 \\
Toplam & $\mathbf{3 5 8}$ & $\mathbf{2 6 , 7 0}$ & $\mathbf{6 . 0 6 0}$ & $\mathbf{. 3 2 0}$ & $\mathbf{1 0 . 0 0}$ & $\mathbf{4 0 , 0 0}$ \\
\hline \multicolumn{2}{c}{$\mathrm{F}(16,341)=1,666$} & $\mathrm{p}=0,000<.05$ & &
\end{tabular}

Tablo 2'de görüldüğü gibi, grupların sözel/ dilsel zekâya ilişkin ortalama puanları 22,57 ile 31,50 arasında değişmektedir. Analiz sonuçları öğretmen adaylarının sözel/dilsel zekâ puanları ile öğrenim gördükleri bölüm arasında anlamlı bir fark bulunduğunu göstermektedir. $\mathrm{F}(16,341)=1,666, \mathrm{p}=.05$, öğretmen adaylarının sözel/dilsel zekâ puanları, öğrenim gördükleri bölüme göre anlamlı bir farklılık göstermektedir. Tukey HSD Testi sonuçlarına göre anlamlı farkın, Resim Öğretmenliği'nde okuyan öğretmen adaylarının ortalaması $(22,57)$ ile Sosyal Bilgiler Eğitimi'nde okuyan öğretmen adaylarının ortalama puanları $(27,90)$ arasında olduğu saptanmıştır. Öğretmen adaylarının aldıkları sözel/dilsel zekâ puanları ortalamalarına bakıldığında, Tarih $(31,50)$ bölümü öğrencilerinin sözel/ dilsel zekâya ilişkin ortalama puanları en yüksek ve Resim Öğretmenliği $(22,57)$ bölümü öğrencilerinin sözel/ dilsel zekâya ilişkin ortalama puanları en düşüktür.

3.2. Mantıksal/ Matematiksel Zekâ Alanı: Öğretmen adaylarının devam ettikleri bölümlere göre, mantıksal/matematiksel zekâ alanı alt boyutuna ilişkin toplam puanları incelenmiş ve inceleme sonuçları Tablo 3 'te sunulmuştur.

Tablo 3. Mantıksal/Matematiksel Zekâya İlişkin Ortalama ve Standart Sapma Sonuçları

\begin{tabular}{lcccccc}
\hline Bölüim & Sayı & Ortalama & $\begin{array}{l}\text { Standart } \\
\text { Sapma }\end{array}$ & $\begin{array}{l}\text { Standart } \\
\text { Hata }\end{array}$ & $\begin{array}{l}\text { Minimum } \\
\text { Değer }\end{array}$ & $\begin{array}{l}\text { Maksimum } \\
\text { Değer }\end{array}$ \\
\hline Sosyal Bilgiler & 80 & 22.40 & 6.783 & .758 & 8.00 & 37.00 \\
PDR & 60 & 23.56 & 7.321 & .945 & 5.00 & 40.00 \\
Fen Bilgisi & 41 & 26.90 & 6.232 & .973 & 8.00 & 38.00 \\
BÖTE & 29 & 29.06 & 6.307 & 1.171 & 17.00 & 39.00 \\
Sosyoloji & 28 & 21.28 & 8.839 & 1.670 & 6.00 & 38.00 \\
Hemşirelik & 24 & 26.62 & 7.234 & 1.476 & 7.00 & 36.00 \\
Resim Öğretmenliği & 19 & 22.47 & 5.728 & 1.314 & 8.00 & 33.00 \\
İşletme & 18 & 20.55 & 7.366 & 1.736 & 5.00 & 30.00 \\
Müzik Öğretmenliği & 15 & 26.00 & 6.436 & 1.661 & 16.00 & 39.00 \\
Sinıf Öğretmenliği & 9 & 30.88 & 5.840 & 1.946 & 21.00 & 40.00 \\
Arkeoloji & 8 & 18.75 & 5.800 & 2.050 & 11.00 & 26.00 \\
\hline
\end{tabular}




\begin{tabular}{lcccccc}
\hline Beden Eğitimi & 7 & 20.57 & 5.094 & 1.925 & 13.00 & 27.00 \\
Tarih & 6 & 22.83 & 8.109 & 3.310 & 14.00 & 37.00 \\
Matematik & 5 & 29.20 & 4.147 & 1.854 & 26.00 & 36.00 \\
Kamu & 4 & 20.00 & 8.286 & 4.143 & 10.00 & 29.00 \\
Radyo, TV, Sinema & 3 & 21.00 & 4.582 & 2.645 & 17.00 & 26.00 \\
İlahiyat & 2 & 19.00 & 2.828 & 2.000 & 17.00 & 21.00 \\
Toplam & $\mathbf{3 5 8}$ & $\mathbf{2 4 . 0 5}$ & $\mathbf{7 . 3 3 3}$ & $\mathbf{. 3 8 7}$ & $\mathbf{5 . 0 0}$ & $\mathbf{4 0 . 0 0}$ \\
\hline
\end{tabular}

$\mathrm{F}(16,341)=3,962$

$\mathrm{p}=0,000<0,05$

Tablo 3 'te görüldüğü gibi, grupların mantıksal/matematiksel zekâya ilişkin ortalama puanları 18,75 ile 30,89 arasında değiş̧mektedir. Analiz sonuçları öğretmen adaylarının mantıksal/matematiksel zekâ puanları ile öğrenim gördükleri bölüm arasında anlamlı bir fark bulunduğunu göstermektedir. $\quad \mathrm{F}(16,341)=3,962, \quad \mathrm{p}<0,05, \quad$ öğretmen adaylarının mantıksal/matematiksel zekâ puanları, öğrenim gördükleri bölüme göre anlamlı bir farklılık göstermektedir. Tukey HSD Testi sonuçlarına göre anlamlı farkın, Bilgisayar ve Öğretim Teknolojileri Bölümü'nde (BÖTE) okuyan öğretmen adaylarının ortalaması $(29,06)$ ile Sosyal Bilgiler $(22,40)$, Sosyoloji $(21,28)$, Psikolojik Danışmanlık ve Rehberlik (PDR) $(23,56)$, İşletme $(20,55)$, Arkeoloji $(18,75)$ bölümlerinde okuyan öğretmen adaylarının ortalama puanları arasında olduğu saptanmıştır. Yine aynı testin sonuçlarına göre Sınıf Öğretmenliği öğretmen adaylarının ortalamaları $(30,89)$ ile Sosyal Bilgiler Öğretmenliği $(22,40)$, Sosyoloji $(21,28)$ ve Arkeoloji $(18,75)$ bölümü öğretmen adaylarının ortalama puanları arasında da anlamlı fark saptanmıştır. Öğretmen adaylarının aldıkları mantıksal/matematiksel zekâ puanları ortalamalarına bakıldığında, Sınıf Öğretmenliği'nde $(30,89)$ okuyan öğretmen adaylarının mantıksal/matematiksel zekâya ilişkin ortalama puanları en yüksek ve Arkeoloji Bölümü'nde $(18,75)$ okuyan öğretmen adaylarının mantıksal/matematiksel zekâya ilişkin ortalama puanları en düşüktür.

3.3. Görsel/Zekâ Alanı: Öğretmen adaylarının eğitim gördükleri bölümlere göre, mantıksal/matematiksel zekâ alanı açısından incelenmiş ve inceleme sonuçları Tablo 4 'te sunulmuştur.

Tablo 4. Görsel/Uzamsal Zekâya Iliş̧kin Ortalama ve Standart Sapma Sonuçları

\begin{tabular}{lcccccc}
\hline Bölüm & Sayı & Ortalama & $\begin{array}{l}\text { Standart } \\
\text { Sapma }\end{array}$ & $\begin{array}{l}\text { Standart } \\
\text { Hata }\end{array}$ & $\begin{array}{l}\text { Minimum } \\
\text { Değer }\end{array}$ & $\begin{array}{l}\text { Maksimum } \\
\text { Değer }\end{array}$ \\
\hline Sosyal Bilgiler & 80 & 25.91 & 5.677 & .634 & 13.00 & 38.00 \\
PDR & 60 & 24.25 & 5.721 & .738 & 12.00 & 37.00 \\
Fen Bilgisi & 41 & 26.41 & 6.741 & 1.052 & 13.00 & 39.00 \\
BÖTE & 29 & 25.89 & 6.073 & 1.127 & 13.00 & 36.00 \\
Sosyoloji & 28 & 27.46 & 6.957 & 1.314 & 12.00 & 39.00 \\
Hemşirelik & 24 & 26.91 & 5.372 & 1.096 & 13.00 & 35.00 \\
Resim Öğretmenliği & 19 & 28.94 & 5.835 & 1.33875 & 21.00 & 38.00 \\
İşletme & 18 & 23.83 & 6.972 & 1.643 & 7.00 & 34.00 \\
Müzik Öğretmenliği & 15 & 27.00 & 5.618 & 1.45078 & 19.00 & 38.00 \\
\hline
\end{tabular}




\begin{tabular}{lcccccc}
\hline Sinıf Öğretmenliği & 9 & 31.33 & 4.898 & 1.632 & 24.00 & 40.00 \\
Arkeoloji & 8 & 29.75 & 4.367 & 1.544 & 23.00 & 35.00 \\
Beden Eğitimi & 7 & 25.00 & 6,403 & 2.420 & 16.00 & 35.00 \\
Tarih & 6 & 28.50 & 9.268 & 3.783 & 16.00 & 39.00 \\
Matematik & 5 & 28.60 & 5.899 & 2.638 & 22.00 & 36.00 \\
Kamu & 4 & 32.00 & 5.597 & 2.798 & 25.00 & 37.00 \\
Radyo, TV, Sinema & 3 & 27.00 & 1.000 & .577 & 26.00 & 28.00 \\
İlahiyat & 2 & 29.00 & 2.828 & 2.000 & 27.00 & 31.00 \\
Toplam & $\mathbf{3 5 8}$ & $\mathbf{2 6 . 3 6}$ & $\mathbf{6 . 1 5 5}$ & $\mathbf{. 3 2 5 3 2}$ & $\mathbf{7 . 0 0}$ & $\mathbf{4 0 . 0 0}$ \\
\hline \multicolumn{2}{c}{$\mathrm{F}(16,341)=1,890$} & $\mathrm{p}=0,02<0,05$ & &
\end{tabular}

Tablo 4'te görüldüğg̈ gibi, grupların görsel/uzamsal zekâya ilişkin ortalama puanları 23,83 ile 32,00 arasında değişmektedir. Analiz sonuçları öğretmen adaylarının görsel/uzamsal zekâ puanları ile öğrenim gördükleri bölüm arasında anlamlı bir fark bulunduğunu göstermektedir. $\mathrm{F}(16,341)=1,890, \mathrm{p}<0,05$, öğretmen adaylarının görsel/uzamsal zekâ puanları, öğrenim gördükleri bölüme göre anlamlı bir farklılık göstermektedir. Öğretmen adaylarının aldıkları görsel/uzamsal zekâ puanları ortalamalarına bakıldığında, sözel zekâ alanı (29,00 puanla) daha yüksek olması beklenen Kamu Yönetimi Bölümü $(32,00)$ öğretmen adaylarının görsel/uzamsal zekâya ilişkin ortalama puanları en yüksek; İşletme Bölümü $(23,83)$ öğretmen adaylarının görsel/uzamsal zekâya ilişkin ortalama puanları ise en düşüktür.

3.4. Müziksel/Ritmik Zekâ Alanı: Öğretmen adaylarının puanları eğitim gördükleri bölümlere göre, müziksel/ritmik zekâ alanı açısından incelenmiş ve inceleme sonuçları Tablo 5 'te sunulmuştur.

Tablo 5. Müziksel/Ritmik Zekâ Alanına İlişkin Ortalama ve Standart Sapma Sonuçları

\begin{tabular}{lcccccc}
\hline Bölüm & Sayı & Ortalama & $\begin{array}{l}\text { Standart } \\
\text { Sapma }\end{array}$ & $\begin{array}{l}\text { Standart } \\
\text { Hata }\end{array}$ & $\begin{array}{l}\text { Minimum } \\
\text { Değer }\end{array}$ & $\begin{array}{l}\text { Maksimum } \\
\text { Değer }\end{array}$ \\
\hline Sosyal Bilgiler & 80 & 24.66 & 6.472 & .723 & 6.00 & 39.00 \\
PDR & 60 & 24.31 & 7.338 & .947 & 6.00 & 40.00 \\
Fen Bilgisi & 41 & 24.60 & 7.154 & 1.117 & 6.00 & 40.00 \\
BÖTE & 29 & 22.34 & 7.167 & 1.331 & 7.00 & 35.00 \\
Sosyoloji & 28 & 26.85 & 9.845 & 1.860 & 3.00 & 40.00 \\
Hemşirelik & 24 & 20.33 & 8.196 & 1.673 & 1.00 & 36.00 \\
Resim Öğretmenliği & 19 & 24.31 & 6.872 & 1.576 & 13.00 & 38.00 \\
İşletme & 18 & 18.11 & 7.095 & 1.672 & 4.00 & 29.00 \\
Müzik Öğretmenliği & 15 & 33.80 & 6.909 & 1.784 & 17.00 & 44.00 \\
Sinıf Öğretmenliği & 9 & 28.77 & 7.579 & 2.526 & 12.00 & 38.00 \\
Arkeoloji & 8 & 21.75 & 7.887 & 2.788 & 4.00 & 29.00 \\
Beden Ĕğitimi & 7 & 30.42 & 5.769 & 2.180 & 23.00 & 39.00 \\
\hline
\end{tabular}




\begin{tabular}{lcccccc}
\hline Tarih & 6 & 26.33 & 5.853 & 2.389 & 20.00 & 35.00 \\
Matematik & 5 & 26.60 & 7.924 & 3.544 & 13.00 & 33.00 \\
Kamu & 4 & 18.25 & 1.500 & .750 & 17.00 & 20.00 \\
Radyo, TV, Sinema & 3 & 25.33 & 6.110 & 3.527 & 20.00 & 32.00 \\
İlahiyat & 2 & 29.00 & 5.656 & 4.000 & 25.00 & 33.00 \\
Toplam & $\mathbf{3 5 8}$ & $\mathbf{2 4 . 4 9}$ & $\mathbf{7 . 7 7 7}$ & $\mathbf{. 4 1 1}$ & $\mathbf{1 , 0 0}$ & $\mathbf{4 4 . 0 0}$ \\
\hline & & $\mathrm{F}(16,341)=4,061$ & $\mathrm{p}=0,000<0,05$ & &
\end{tabular}

Tablo 5'te görüldüğü gibi, grupların müziksel/ritmik zekâya ilişkin ortalama puanları 18,11 ile 33,80 arasında değişmektedir. Analiz sonuçları öğretmen adaylarının müziksel/ritmik zekâ puanları ile öğrenim gördükleri bölüm arasında anlamlı bir fark bulunduğunu göstermektedir. $\mathrm{F}(16,341)=4,061, \mathrm{p}<0,05$, öğretmen adaylarının müziksel/ritmik zekâ puanları, öğrenim gördükleri bölüme göre anlamlı bir farklılık göstermektedir.

Tukey HSD Testi sonuçlarına göre anlamlı farkın Müzik Öğretmenliği Bölümü’nde okuyan öğretmen adaylarının ortalaması $(33,80)$ ile BÖTE $(22,34)$, Sosyal Bilgiler Öğretmenliği $(24,66)$, Hemşirelik $(20,33)$, PDR $(24,31)$, İşletme $(18,11)$, Kamu Yönetimi $(18,25)$, Arkeoloji (21,75), Fen Bilgisi Öğretmenliği $(24,60)$ ve Resim Öğretmenliği $(24,31)$ bölümlerinde okuyan öğretmen adaylarının arasında olduğu görülmektedir.

Öğretmen adaylarının aldıkları müziksel/ritmik zekâ puanları ortalamalarına bakıldığında Müzik Öğretmenliği Bölümü $(33,80)$ öğretmen adaylarının müziksel/ritmik zekâya ilişkin ortalama puanları en yüksek ve İşletme Bölümü $(18,11)$ öğretmen adaylarının müziksel/ritmik zekâya ilişkin ortalama puanları en düşüktür.

3.5. Bedensel/Kinestetik Zekâ Alanı: Öğretmen adaylarının puanları eğitim gördükleri bölümlere göre, bedensel/kinestetik zekâ alanı açısından incelenmiş ve inceleme sonuçları Tablo 6'da sunulmuştur.

Tablo 6. Bedensel/Kinestetik Zekâ Alanına İlișkin Ortalama ve Standart Sapma Sonuçları

\begin{tabular}{lcccccc}
\hline Bölüm & Sayı & Ortalama & $\begin{array}{l}\text { Standart } \\
\text { Sapma }\end{array}$ & $\begin{array}{l}\text { Standart } \\
\text { Hata }\end{array}$ & $\begin{array}{l}\text { Minimum } \\
\text { Değer }\end{array}$ & $\begin{array}{l}\text { Maksimum } \\
\text { Değer }\end{array}$ \\
\hline Sosyal Bilgiler & 80 & 27.03 & 6.967 & .778 & 13.00 & 40.00 \\
PDR & 60 & 24.30 & 8.036 & 1.037 & 5.00 & 42.00 \\
Fen Bilgisi & 41 & 26.41 & 8.840 & 1.380 & 10.00 & 40.00 \\
BÖTE & 29 & 23.10 & 7.654 & 1.421 & 9.00 & 38.00 \\
Sosyoloji & 28 & 27.53 & 7.490 & 1.415 & 11.00 & 40.00 \\
Hemşirelik & 24 & 27.00 & 7.312 & 1.492 & 13.00 & 38.00 \\
Resim Öğretmenliği & 19 & 26.47 & 7.486 & 1.717 & 14.00 & 40.00 \\
İşletme & 18 & 24.83 & 9.432 & 2.223 & 8.00 & 39.00 \\
Müzik Öğretmenliği & 15 & 27.73 & 6.963 & 1.798 & 16.00 & 39.00 \\
Sinı̈ Öğretmenliği & 9 & 32.44 & 6.654 & 2.218 & 19.00 & 39.00 \\
Arkeoloji & 8 & 27.50 & 7.425 & 2.625 & 16.00 & 37.00 \\
\hline
\end{tabular}




\begin{tabular}{lcccccc}
\hline Beden Eğitimi & 7 & 28.14 & 10.302 & 3.894 & 13.00 & 40.00 \\
Tarih & 6 & 31.16 & 7.678 & 3.134 & 22.00 & 40.00 \\
Matematik & 5 & 26.60 & 5.176 & 2.315 & 19.00 & 32.00 \\
Kamu & 4 & 23.00 & 11.518 & 5.759 & 8.00 & 35.00 \\
Radyo, TV, Sinema & 3 & 25.00 & 12.124 & 7.000 & 14.00 & 38.00 \\
İlahiyat & 2 & 23.50 & 2.121 & 1.500 & 22.00 & 25.00 \\
Toplam & $\mathbf{3 5 8}$ & 26.26 & 7.871 & .416 & 5.00 & 42.00 \\
\hline \multicolumn{7}{r}{} \\
\end{tabular}

Tablo 6'da görüldüğü gibi, grupların bedensel/kinestetik zekâya ilişkin ortalama puanları 23,00 ile 32,44 arasında değişmektedir. Analiz sonuçları öğretmen adaylarının müziksel/ritmik zekâ puanları ile öğrenim gördükleri bölüm arasında anlamlı bir fark bulunmadığını göstermektedir. $\mathrm{F}(16,341)=1,316$ ve $\mathrm{p}>0,05$, öğretmen adaylarının bedensel/kinestetik zekâ puanları, öğrenim gördükleri bölüme göre anlamlı bir farklılık göstermemektedir. Öğretmen adaylarının aldıkları bedensel/kinestetik zekâ puanları ortalamalarına bakıldığında, Sınıf Öğretmenliği’nde $(32,44)$ okuyan öğretmen adaylarının bedensel/kinestetik zekâya ilişkin ortalama puanları en yüksek ve Kamu Yönetimi’nde $(23,00)$ okuyan öğretmen adaylarının bedensel/kinestetik zekâya ilişkin ortalama puanları en düşüktür.

3.6. Doğacı Zekâ Alanı: Öğretmen adaylarının puanları eğitim gördükleri bölümlere göre, doğa zekâ alanı açısından incelenmiş ve inceleme sonuçları Tablo 7'de sunulmuştur.

Tablo 7. Doğacı Zekâ Alanına İlişkin Ortalama ve Standart Sapma Sonuçları

\begin{tabular}{lcccccc}
\hline Bölüm & Sayı & Ortalama & $\begin{array}{l}\text { Standart } \\
\text { Sapma }\end{array}$ & $\begin{array}{l}\text { Standart } \\
\text { Hata }\end{array}$ & $\begin{array}{l}\text { Minimum } \\
\text { Değer }\end{array}$ & $\begin{array}{l}\text { Maksimum } \\
\text { Değer }\end{array}$ \\
\hline Sosyal Bilgiler & 80 & 29.32 & 6.041 & .675 & 3.00 & 39.00 \\
PDR & 60 & 28.86 & 5.591 & .721 & 18.00 & 40.00 \\
Fen Bilgisi & 41 & 28.53 & 4.950 & .773 & 13.00 & 39.00 \\
BÖTE & 29 & 30.44 & 5.268 & .978 & 22.00 & 39.00 \\
Sosyoloji & 28 & 28.57 & 8.080 & 1.527 & 10.00 & 40.00 \\
Hemşirelik & 24 & 26.25 & 6.783 & 1.384 & 13.00 & 34.00 \\
Resim Öğretmenliği & 19 & 26.36 & 7.228 & 1.658 & 6.00 & 33.00 \\
İşletme & 18 & 31.22 & 5.185 & 1.222 & 18.00 & 42.00 \\
Müzik Öğretmenliği & 15 & 30.53 & 4.533 & 1.170 & 21.00 & 39.00 \\
Sinıf Öğretmenliği & 9 & 31.77 & 5.932 & 1.977 & 21.00 & 38.00 \\
Arkeoloji & 8 & 30.00 & 4.472 & 1.581 & 24.00 & 37.00 \\
Beden Eğitimi & 7 & 32.14 & 5.550 & 2.097 & 23.00 & 39.00 \\
Tarih & 6 & 33,66 & 3.777 & 1.542 & 27.00 & 37.00 \\
Matematik & 5 & 26.00 & 8.916 & 3.987 & 16.00 & 38.00 \\
Kamu & 4 & 37.75 & 1.258 & .629 & 36.00 & 39.00 \\
\hline
\end{tabular}




\begin{tabular}{|c|c|c|c|c|c|c|}
\hline Radyo, TV, Sinema & 3 & 33.00 & 1.732 & 1.000 & 31.00 & 34.00 \\
\hline İlahiyat & 2 & 30.50 & 3.535 & 2.500 & 28.00 & 33.00 \\
\hline Toplam & 358 & 29.26 & 6.078 & .321 & 3.00 & 42.00 \\
\hline
\end{tabular}

Tablo 7'de görüldüğü gibi, grupların doğa zekâsına ilişkin ortalama puanları 26,00 ile 37,75 arasında değişmektedir. Analiz sonuçları öğretmen adaylarının doğa zekâsı puanları ile öğrenim gördükleri bölüm arasında anlamlı bir fark bulunduğunu göstermektedir. $\mathrm{F}(16,341)=2,090 \mathrm{p}<0,05$, öğretmen adaylarının doğa zekâsı puanları, öğrenim gördükleri bölüme göre anlamlı bir farkl1lık göstermektedir. Tukey HSD Testi sonuçlarına göre anlamlı farkın, Kamu Yönetimi Bölümü'nde okuyan öğretmen adaylarının ortalama puanı $(37,75)$ ile Hemşirelik Bölümü öğretmen adaylarının ortalama puanları $(26,25)$ arasında olduğu görülmektedir. Öğretmen adaylarının aldıkları doğa zekâsı puanları ortalamalarına bakıldığında, Kamu Yönetimi Bölümü $(37,75)$ okuyanların doğa zekâsına ilişkin ortalama puanları en yüksek ve Matematik Bölümü'nde $(26,00)$ okuyan öğretmen adaylarının doğa zekâsına ilişkin ortalama puanları en düşüktür.

3.7. Kişilerarası Zekâ Alanı: Öğretmen adaylarının puanları eğitim gördükleri bölümlere göre, kişilerarası zekâ alanı açısından incelenmiş ve inceleme sonuçları Tablo 8'de sunulmuştur.

Tablo 8. Kişilerarası Zekâ Alanına İlişkin Ortalama ve Standart Sapma Sonuçları

\begin{tabular}{|c|c|c|c|c|c|c|}
\hline Bölüm & Sayı & Ortalama & $\begin{array}{l}\text { Standart } \\
\text { Sapma }\end{array}$ & $\begin{array}{l}\text { Standart } \\
\text { Hata }\end{array}$ & $\begin{array}{l}\text { Minimum } \\
\text { Değer }\end{array}$ & $\begin{array}{l}\text { Maksimum } \\
\text { Değer }\end{array}$ \\
\hline Sosyal Bilgiler & 80 & 28.32 & 5.914 & .661 & 14.00 & 41.00 \\
\hline PDR & 60 & 27.26 & 5.233 & .675 & 16.00 & 38.00 \\
\hline Fen Bilgisi & 41 & 27.75 & 5.902 & .921 & 10.00 & 39.00 \\
\hline BÖTE & 29 & 30.10 & 5.387 & 1.000 & 21.00 & 39.00 \\
\hline Sosyoloji & 28 & 29.75 & 8.951 & 1.691 & 3.00 & 40.00 \\
\hline Hemşirelik & 24 & 28.54 & 4.800 & .979 & 19.00 & 36.00 \\
\hline Resim Öğretmenliği & 19 & 26.63 & 5.068 & 1.162 & 16.00 & 36.00 \\
\hline İşletme & 18 & 24.94 & 5.945 & 1.401 & 16.00 & 37.00 \\
\hline Müzik Öğretmenliği & 15 & 30.00 & 5.464 & 1.410 & 25.00 & 44.00 \\
\hline Sınıf Öğretmenliği & 9 & 28.33 & 7.262 & 2.420 & 15.00 & 37.00 \\
\hline Arkeoloji & 8 & 27.87 & 5.303 & 1.875 & 16.00 & 33.00 \\
\hline Beden Eğitimi & 7 & 31.57 & 4.503 & 1.702 & 27.00 & 40.00 \\
\hline Tarih & 6 & 32.33 & 2.875 & 1.173 & 28.00 & 36.00 \\
\hline Matematik & 5 & 32.20 & 3.114 & 1.392 & 29.00 & 37.00 \\
\hline Kamu & 4 & 30.25 & 4.573 & 2.286 & 24.00 & 35.00 \\
\hline Radyo, TV, Sinema & 3 & 29.66 & 6.506 & 3.756 & 23.00 & 36.00 \\
\hline İlahiyat & 2 & 31.00 & 5.656 & 4.000 & 27.00 & 35.00 \\
\hline Toplam & 358 & 28.38 & 5.934 & .31365 & 3.00 & 44.00 \\
\hline
\end{tabular}


Tablo 8'de görüldüğü gibi, grupların kişilerarası zekâya ilişkin ortalama puanları 24,94 ile 32,33 arasında değişmektedir. Analiz sonuçları öğretmen adaylarının kişilerarası zekâ puanları ile öğrenim gördükleri bölüm arasında anlamlı bir fark bulunmadığını göstermektedir. $\mathrm{F}(16,341)=1,473, \mathrm{p}>0,05$, öğretmen adaylarının kişilerarası zekâ puanları, öğrenim gördükleri bölüme göre anlamlı bir farklılık göstermemektedir. Öğretmen adaylarının aldıkları kişilerarası zekâ puanları ortalamalarına bakıldığında, Tarih Bölümü'nde $(32,33)$ öğretmen adaylarının kişilerarası zekâya ilişkin ortalama puanları en yüksek ve İşletme Bölümü'nde $(24,94)$ okuyan öğretmen adaylarının kişilerarası zekâya ilişkin ortalama puanları en düşüktür.

3.8. İçsel Zekâ Alanı: Öğretmen adaylarının puanları eğitim gördükleri bölümlere göre, kişilerarası zekâ alanı açısından incelenmiş ve inceleme sonuçları Tablo 9'da sunulmuştur.

Tablo 9. İçsel Zekâ Alanına İlişkin Ortalama ve Standart Sapma Sonuçları

\begin{tabular}{|c|c|c|c|c|c|c|}
\hline Bölüm & Sayı & Ortalama & $\begin{array}{l}\text { Standart } \\
\text { Sapma }\end{array}$ & $\begin{array}{l}\text { Standart } \\
\text { Hata }\end{array}$ & $\begin{array}{l}\text { Minimum } \\
\text { Değer }\end{array}$ & $\begin{array}{l}\text { Maksimum } \\
\text { Değer }\end{array}$ \\
\hline Sosyal Bilgiler & 80 & 28.52 & 5,238 & .585 & 18.00 & 38.00 \\
\hline PDR & 60 & 28.05 & 5,685 & .733 & 17.00 & 42.00 \\
\hline Fen Bilgisi & 41 & 28.60 & 5,073 & .792 & 13.00 & 40.00 \\
\hline BÖTE & 29 & 27.68 & 5,271 & .978 & 18.00 & 36.00 \\
\hline Sosyoloji & 28 & 27.85 & 7,199 & 1.360 & 12.00 & 40.00 \\
\hline Hemşirelik & 24 & 29.25 & 4,55164 & .929 & 21.00 & 40.00 \\
\hline Resim Öğretmenliği & 19 & 27.52 & 4,325 & .992 & 17.00 & 33.00 \\
\hline İşletme & 18 & 28.16 & 4,162 & .981 & 21.00 & 36.00 \\
\hline Müzik Öğretmenliği & 15 & 30.86 & 4,454 & 1.150 & 21.00 & 38.00 \\
\hline Sinıf Öğretmenliği & 9 & 30.22 & 4,294 & 1.431 & 21.00 & 35.00 \\
\hline Arkeoloji & 8 & 28.375 & 3,852 & 1.361 & 24.00 & 36.00 \\
\hline Beden Eğitimi & 7 & 31.00 & 3,696 & 1.397 & 26.00 & 36.00 \\
\hline Tarih & 6 & 30.66 & 3,141 & 1.282 & 26.00 & 35.00 \\
\hline Matematik & 5 & 29.00 & 4,636 & 2.073 & 23.00 & 35.00 \\
\hline Kamu & 4 & 28.25 & 3,095 & 1.547 & 24.00 & 31.00 \\
\hline Radyo, TV, Sinema & 3 & 29.66 & 3,055 & 1.763 & 27.00 & 33.00 \\
\hline İlahiyat & 2 & 23.00 & 1,414 & 1.000 & 22.00 & 24.00 \\
\hline Total & 358 & 28.51 & 5,161 & .272 & 12.00 & 42.00 \\
\hline
\end{tabular}

Tablo 9'da görüldügü gibi, grupların içsel zekâya ilişkin ortalama puanları 23,00 ile 31,00 arasında değişmektedir. Analiz sonuçları, öğretmen adaylarının içsel zekâ puanları ile öğrenim gördükleri bölüm arasında anlamlı bir fark bulunmadığını göstermektedir. $\mathrm{F}(16,341)=0,755, \mathrm{p}>0,05$, öğretmen adaylarının içsel zekâ puanları, öğrenim gördükleri bölüme göre anlamlı bir farklılık göstermemektedir. Öğretmen adaylarının aldıkları içsel zekâ alanı alt boyutundan aldıkları toplam puan ortalamalarına bakıldığında, Beden Eğitimi 
Bölümü $(31,00)$ öğretmen adaylarının içsel zekâya ilişkin ortalama puanları en yüksek ve İlahiyat Bölümü $(23,00)$ öğretmen adaylarının içsel zekâya ilişkin ortalama puanları en düşüktür.

\section{Sonuç, Tartışma ve Öneriler}

Öğretmen adayları için hem kendi öğrenme hem de öğrencilerin sahip olduğu farklı öğrenme yollarının farkında olması ve tüm öğrenenlere yönelik çoklu öğrenme-öğretme çevresi hazırlayabilme becerisi önemlidir. $\mathrm{Bu}$ nedenle de öğretmen adaylarının çoklu zekâ yaklaşımına ilişkin öz-farkındalığı belirlenmelidir. Bu çalışmada elde edilen önemli bulgulardan biri, Resim öğretmeni adaylarının görsel-uzamsal zekâ bölümüne ilișkin ortalama puanlarının ( $\bar{x}: 24.31$ ) görece düşük olmasıdır. Oysaki beklenen, görsel uzamsal zekâ alanına ilişkin olarak kendilerini daha iyi algılamalarıdır. Keza, Beden Eğitimi öğretmen adaylarının, bedensel-kinestetik zekâ bölümü ortalamaları ( $\mathrm{x}:$ 28.14) da görece düşüktür. Bir diğer önemli bulgu ise, Müzik Eğitimi öğretmen adaylarının müziksel-ritmik zekâ bölümü ortalama puanları açısından en yüksek ortalamaya sahip olması ( $\bar{x}$ : 33.20); bunun arkasından Beden Eğitimi öğretmen adaylarının ( $\overline{\mathrm{x}}$ : 30.42) onları takip etmesi oldukça önemlidir. Burada öğretmen yetiştirme programlarında bölümlere göre farklı zekâ alanlarına ilişkin olarak farkındalık yaratılması önem taşımaktadır.

Yine öğretmen adaylarına özellikle doğacı, içsel ve kişiler arası zekâ bölümlerinde genel puan ortalamalarının diğer zekâ bölümlerine göre daha yüksek çıkması dikkat çekici bir bulgudur. $\mathrm{Bu}$ durumu, öğretmen yetiştirme programlarında çevresel farkındalık vurgulu mesajların derslerin ağırlığının artırılması ve medyanın farkındalık yaratmadaki etkisi ile açıklanabilir. İçsel ve kişiler arası zekâ puanlarının görece yüksek olmasındaki etken de araştırma yapılan grubun öğretmen adayları olmasından kaynaklanabilir. Hem pedagojik formasyon hem de eğitim fakültesinde yürütülen öğretmen yetiştirme programının etkisi, bireyin içsel zekâsına ve kişilerarası zekâ bölümüne ilişkin farkındalığın artmasını desteklemektedir. Güneş ve Gökçek de (2010) farklı bölümlerde öğrenim gören eğitim fakültesi öğrencilerinin tümünün özedönük-içsel zekâ türünde çok gelişmiş düzeyde olduklarını belirlemiştir. Yenice ve Aktamış (2010) sınıf öğretmeni adaylarının çoklu zekâ kuramına dayalı zekâ alanlarını tespit etmek ve çoklu zekâ ile ilişkili etmenleri araştırmak amacıyla bir çalışma yapmışlardır. Araştırma sonucunda Sınıf Öğretmenliği Anabilim dalında öğrenim gören öğretmen adaylarının çoklu zekâ kuramına dayalı zekâ alanlarına dağılımları ve zekâ alanları ile öğretmen adaylarının okumakta oldukları öğrenim türü (örgün veya ikinci öğretim), cinsiyeti, mezun oldukları okul türü, lise düzeyinde seçtikleri alan arasındaki farklılıklar belirlenmiştir. Öğrencilerin zekâ alanlarına dağılımları ortalaması incelendiğinde bütün zekâ alanlarında "orta düzeyde gelişmişs” șeklinde homojen bir dağılım olduğu görülmüştür. Yalmanc1 (2011) eğitim fakültesi öğrencilerinde algılanan çoklu zekâ türleri ile öğretmen adaylarının öğrenim gördükleri bölümler arasındaki (Sınıf Öğretmenliği, Sosyal Bilgiler, Fen Bilgisi Öğretmenliği ve Türkçe Öğretmenliği Bölümü) ilişkiyi incelemiştir. Araştırmanın sonucunda, öğretmen adaylarının mantıksal-matematiksel, görseluzamsal zekâ ve sosyal zekâ türleriyle, öğrenim gördükleri bölümler arasında anlamlı bir farklılık ortaya çıkmıştır. Akkaya ve Sezgin Memnun da (2015), Matematik Öğretmenliğinde öğrenim görmekte olan 145 öğretmen adayına Çoklu Zekâa Alanları Envanteri uygulamıştır. Çalışmanın sonunda, ilköğretim matematik öğretmeni adaylarının mantıksal-matematiksel, kişilerarası-sosyal ve içsel-içedönük zekâ alanlarının gelişmiş ve diğer zekâ alanlarının ise orta düzeyde gelişmiş olduğu belirlenmiştir. 
Yenice, Özden ve Alpak-Tunç (2016) tarafından yapılan bir diğer çalışmada Fen Bilgisi öğretmen adaylarının çoklu zekâ alanları ile çevreye yönelik tutumları arasındaki ilişkiyi belirlemek amaçlanmıştır. Araştırma sonucunda, Fen Bilgisi öğretmen adaylarının çoklu zekâ envanterine göre en yüksek puan aldıkları zekâ alanlarının mantıksal/matematiksel ve bedensel/kinestetik zekâ alanları olduğu, bu alanları sırasıyla görsel/uzamsal, sosyal/bireylerarası, içsel/ özedönük, doğacı/doğa, müzikal/ritmik ve sözel/dilsel zekâ alanlarının izlediği sonucuna ulaşılmıştır. Ayrıca öğretmen adaylarının sözel/dilsel zekâ alanı dışındaki diğer zekâ alanlarında, çoklu zekâ envanterine göre gelişmiş düzeyde olduğu tespit edilmiştir. Sözel/Dilsel zekâ alanının ise Çoklu Zekâ Envanterine göre orta düzeyde olduğu belirlenmiştir. Geleneksel eğitim anlayışında geleneksel bir öğretmen sözel/dilsel zekâ alanını daha çok kullanmaktadır. Bu çalışmada ise, Fen Bilgisi öğretmen adaylarının, çoklu zekâ envanteri alt boyutları açısından en yüksek puanı doğacı zekâ bölümünden almaları dikkat çekicidir. Özetle, öğretmen adaylarının devam ettikleri öğretmenlik programı ile algılanan çoklu zekâ bölümleri arasında sınırlı sayıda ilişkili bulgular belirlenmiştir.

Sınıf Öğretmeni adaylarına bakıldığında, bedensel kinestetik, görsel uzamsal ve içsel zekâ alanlarında görece yüksek ortalamaya sahip olmaları, hibrit bir eğitim programına sahip olmaları ile açıklanabilir. Sınıf öğretmenliği programı, temel bilim alanlarını derinlemesine sunan bir içeriğe sahip değildir. 6-10 yaş çocukların gelişimsel düzeylerine göre, farklı temel bilim alanlarını disiplinlerarası bir anlayışla ele aldığı için hibrit bir yapıya sahiptir. Özetle, Çoklu Zekâ Kuramı açısından bakıldığında, bazı öğretmenlik alanlarına devam eden öğrencilerin, devam ettikleri bölüm ile ilişkili zekâ alanlarında görece yüksek puan aldıkları; bazı bölümlerde ise bu ilişkinin zayıf olduğu görülmektedir. Eğitim Fakülteleri ve Pedagojik Formasyon programlarında öğretmen adaylarına bu farkındalığın kazandırılması önemlidir. Yeni araştırmaların öğretmenlik mesleğini ilgilendiren alanlar dışında da sürdürülmesi farklı meslek tercihleri ile kişilerin çoklu zekâ algısı arasındaki ilişkileri bulmak ve öğretmenlik mesleğini icra edenlerin çoklu zekâ algıları ile karşılaştırmak açısından yararlı olabilir. Diğer taraftan, bu çalışmanın en büyük sınırlılığ alınarak, farklı öğretmenlik alanlarının çoklu zeka algılarını karşılaştıran çalışmaların yapılması önerilebilir. 


\section{KAYNAKÇA}

AKKAYA, R. ve SEZGİN MEMNUN, D. (2015). Matematik Öğretmeni Adaylarının Kullandıkları Çoklu Zekâ Alanları. Dumlupınar Üniversitesi Sosyal Bilimler Dergisi, $43,39-46$.

ARMSTRONG, T. (1994). Multiple Intelligences in the Classroom, Alexandria, VA: Association for Supervision and Curriculum Development.

AZAR, A., PRESLEY, A. ve BALKAYA, Ö. (2006). Çoklu Zekâ Kuramına Dayalı Öğretimin Öğrencilerin Başarı, Tutum, Hatırlama ve Bilişsel Süreç Becerilerine Etkisi, Hacettepe Üniversitesi Ĕgitim Fakültesi Dergisi, 30, 45-54.

CAMPBELL, L. (1996). Teaching \& Learning Through Multiple Intelligences, Needham, Massachusetts: A Simon \& Schuster Company.

GARDNER, H. (1993). Multiple Intelligences: The Theory in Practice. New York: BasicBooks.

GÜNEŞ, G. ve GÖKÇEK, T. (2010). A Casestudy on the Graduate Students' Multiple Intelligence Types. Illkögretim Online (Elementary Education Online), 9(2), 459-473. http://ilkogretim-online.org.tr (Erişim Tarihi,08.07.2017).

KABAPINAR, Y. (2007). İlkögretimde Hayat Bilgisi ve Sosyal Bilgiler Öğretimi. Ankara. Maya Akademi.

KARASAR, N. (2009). Bilimsel Araştırma Yöntemi. Ankara: Nobel.

KEPPEL, G. (1993). Introduction to Design and Analysis: A Student's Handbook. New York, NY: W.H. Freeman and Company.

LAZEAR, D. (1992). Teaching for Multiple Intelligences. Fastback 342 Bloomington, IN: Phi Delta KappanEducational Foundation. (ED 356 227).

NOBLE, T. (2004). Integrating the Revised Bloom's Taxonomy with Multiple Intelligences: A Planning Tool for Curriculum Differenciences, Teachers College Record, vol. 106, 193-211.

SABAN, A. (2002). Çoklu Zekâ Teorisi ve Eğitim. Ankara: Nobel.

YALMANCI, S.G. (2011). Çoklu Zekâ Türleri ile Öğretmen Adaylarının Öğrenim Gördükleri Bölümler Arasındaki İlişki. Uluslararası İnsan Bilimleri Dergisi. 8(1), 1269-1289.

YENICE, N. ve AKTAMIŞ, H. (2010). Sınıf Öğretmeni Adaylarının Çoklu Zekâ Alanlarının Demografik Özelliklere Göre İncelenmesi. Türk Fen Ĕ̈itim Dergisi. 7(3), 86-99.

YENICE, N., ÖZDEN, B. ve ALPAK TUNÇ, G.(2016). Fen Bilgisi Öğretmen Adaylarının Çoklu Zekâ Alanları ile Çevreye Yönelik Tutumları Arasındaki İlişkinin İncelenmesi. Hasan Ali Yücel Eğitim Fakültesi Dergisi, 13-3(26), 83-97. 